\title{
Influence of Two DNA Repair Pathway Polymorphisms in Colorectal Cancer Risk in Southwest Iran
}

\author{
Seyed Mohammad Hosseini ${ }^{1}$, Javad Mohammadiasl, Abdolhasan Talaiezadeh ${ }^{2,3}$, \\ Rahim Alidadi ${ }^{1}$, Mahdi Bijanzadeh ${ }^{1,2 *}$
}

\begin{abstract}
Objective: X-ray cross-complementing group $1(X R C C 1)$ and 8 Oxo guanine DNA-glycosylase 1 (OGG1) genes are implicated in the repair of single-stranded breaks (SSBRs) and base excision repair (BER) pathways. Common polymorphisms in DNA repair genes are supposed to decrease the capability of DNA repair and cause genetic instability. This study was designed to investigate the association between XRCC1 (rs25487) and OGG1 (rs1052133) polymorphisms and susceptibility to colorectal cancer (CRC) in the Ahvaz city, south-west Iran. Methods: This case- control study comprised 150 patients and 150 controls that were selected from 2 educational hospitals in Ahvaz. They were matched for age and gender, and their genotyping was carried out by polymerase chain reaction-restriction fragment length polymorphism (PCR-RFLP). Results: Our results indicate that the frequency of the Gln (A) allele of XRCC1 (rs 25487) is significantly higher in colorectal cancer patients, compare to controls ( $\mathrm{p}=0.01,0 \mathrm{OR}: 1.54,95 \%$ CI 1.9-13.3). Significant increased risk of cancer was observed in XRCC1 (rs25487) genotypes (p = 0.001 OR: 5.3, 95\% CI 1.9-14.2 for Gln / Gln), while no association was found between OGG1 (rs1052133) and colorectal cancer risk $(\mathrm{p}=0.6)$. Conclusion: Our study suggests that XRCC1 ( $r$ 25487) polymorphism might be associated with an increasing risk of CRC in Ahvaz. It also demonstrates positive correlation between the XRCC1 (rs25487) genotypes and demographic characteristics, such as smoking and increased age in patients and control groups.
\end{abstract}

Keywords: Polymorphism- colorectal cancer- restriction fragment length polymorphism

Asian Pac J Cancer Prev, 21 (7), 1919-1924

\section{Introduction}

Colorectal cancer $(\mathrm{CRC})$ is one of the most common malignancies and the fourth leading cause of death by cancer in the world (Arnold et al., 2017). The incidence of colorectal cancer seems to have increased in Iran: occurrence of CRC has increased with age and highest rates have been observed in the older peoples (Safaee et al., 2012). CRC is a complex disorder caused by the composite of genetic susceptibilities and environmental factors. Diet, smoking, and alcohol consumption are environmental factors that have shown association with CRC risk (Pardini et al., 2008). Candidate genes considered susceptible to CRC are implicated in tumor suppressor genes, oncogenes, methylation mechanism, and genes involved in DNA repair pathways (de Jong et al., 2002). In mammalian cells, four important mechanisms of DNA repair have been recognized: nucleotide excision repair (NER), base excision repair (BER), double-strand break repair, and mismatch repair (Karam et al., 2016). Some common genetic polymorphisms in DNA repair genes are supposed to decrease capability of DNA repair and genetic instability that may contribute to the development of cancers such as CRC (Wood et al., 2001). Among the established polymorphisms of the DNA repair genes, the X-ray cross-complementing group 1 (XRCC1) and 8 Oxo guanine DNA-glycosylase 1 (OGG1) polymorphisms have been frequently studied as potentially related with susceptibility to the incidence of several cancers (Simonelli et al., 2012; Nissar et al., 2014). The DNA repair gene $X R C C 1$ is implicated in the repair of single-stranded breaks (SSBRs) and base excision repair (BER) that has been mapped to the human chromosome region 19q13 (Mohrenweiser et al., 1989; Huang et al., 2015). Another DNA repair gene that has an essential role in base excision repair is $O G G 1$ that is located in the chromosome region $3 \mathrm{p} 26$. This glycosylase enzyme removes damaged bases by way of reactive oxygen. XRCC1 has unknown enzymatic activity and is considered to operate as a scaffold protein for base

${ }^{1}$ Department of Medical Genetics, Faculty of Medicine, Ahvaz Jundishapur University of Medical Sciences, Ahvaz, Iran. ${ }^{2}$ Cancer, Environmental and Petroleum Pollutants Research Center, Ahvaz Jundishapur University of Medical Sciences, Ahvaz, Iran. ${ }^{3}$ Department of General Surgery, School of Medicine, Ahvaz Jundishapur University of Medical Sciences, Ahvaz, Iran. *For Correspondence:mbijanz@yahoo.com 
excision repair activities (Hung et al., 2005). XRCC1 has been reported to interact with other crucial proteins such as DNA polymerase $\beta$, DNA ligase III, poly (ADP-ribose) polymerase, APE1, and OGG1 in base excision repair pathway (Fan et al., 2004; Nazarkina et al., 2007). One of the common genetic polymorphism in the XRCC1 gene is Arg399Gln (rs25487) at amino acid residue 399 (Arg to Gln) of exon 10: this substitution can alter the functionality of XRCC1 protein and damage its DNA repair activity (Monaco et al., 2007). The OGG1 is an important DNA repair gene that encodes a DNA glycosylase for removal of the 8-oxoG adduct of oxidatively damaged DNA(Weiss et al., 2005). Although many polymorphisms have been reported, Ser326Cys (rs1052133) polymorphism at the codon 326 of exon 7 (Ser to Cys) in OGG1 gene is the most studied polymorphism (Boiteux and Radicella, 2016). It has been reported to affect the OGG1 function and is linked to increased risk of different cancers (Kohno et al., 1998, Wang et al., 2015). Therefore, this study was designed to investigate the association between the polymorphisms of DNA repair genes, including XRCC1 (rs25487) and OGG1 (rs 1052133) given their susceptibility to colorectal cancer in the Ahvaz city, south-west Iran.

\section{Materials and Methods}

\section{Study population}

This study comprised 150 patients (82 males and 68 females) with mean age $54.89 \pm 13.5 \mathrm{SD}$ and 150 controls (70 males and 80 females) with mean age $55.09 \pm 11.5 \mathrm{SD}$. Informed consent was obtained from all participants for their participation in the study. The ethics committee of the Jundishapur University of Medical Sciences approved the study. An organized questionnaire was applied to collect information from study subjects about lifestyle habits (smoking, diet, and alcoholism). Patients include subjects with positive colonoscopic findings for malignancy and histologically accepted as carcinomas of colorectal. The control subjects were picked among individuals who refers to hospital with no evidence and history of cancer. Patients and controls were matched were age and gender. Our exclusion criteria for control group are personal history of all cancers and chronic diseases such as hypertension, diabetes mellitus, and nephritic disorder. Patients who were receiving neoadjuvant chemotherapy and suffered from autoimmune and metabolic diseases were excluded from the study.

\section{DNA extraction and genotyping}

DNA for genotyping was isolated from whole blood samples ( $5 \mathrm{ml}$ collected into EDTA tubes) taken from CRC patients and control subjects. DNA extraction was performed by DNA Extraction Kit (Favorgen Biotech, Taiwan) conforming to the manufacturer's procedure.

Genotyping was carried out by restriction fragment length polymorphism (RFLP) after polymerase chain reaction (PCR); detailed information of procedures for PCR-RFLP is shown in Table 1.

\section{Statistical analysis}

The differences of genotype frequencies of the $X R C C 1$ and $O G G 1$ gene polymorphisms between clinical features within the cases and controls were analysed using the Chi-square test. Association between these polymorphisms and CRC was calculated with $95 \%$ odds ratios (OR) and confidence intervals (CI). p value $<0.05$ was considered statistically significant. Adjusted Odds ratio (OR), 95\% confidence intervals (CIs), and p-values were determined by logistic regression in order to evaluate the association between each genotype and risk of CRC. The binary logistic regression model included age, gender, and smoking. All statistical analysis was performed using the SPSS software for Windows version 18.0 (SPSS, Chicago, IL, USA).

\section{Results}

Out of 150 patients, 49 patients $(32.7 \%)$ had less than 50 years and $101(67.3 \%)$ had more than 50 years old, compare to 46 controls (30.7\%) less than 50 years

A

B

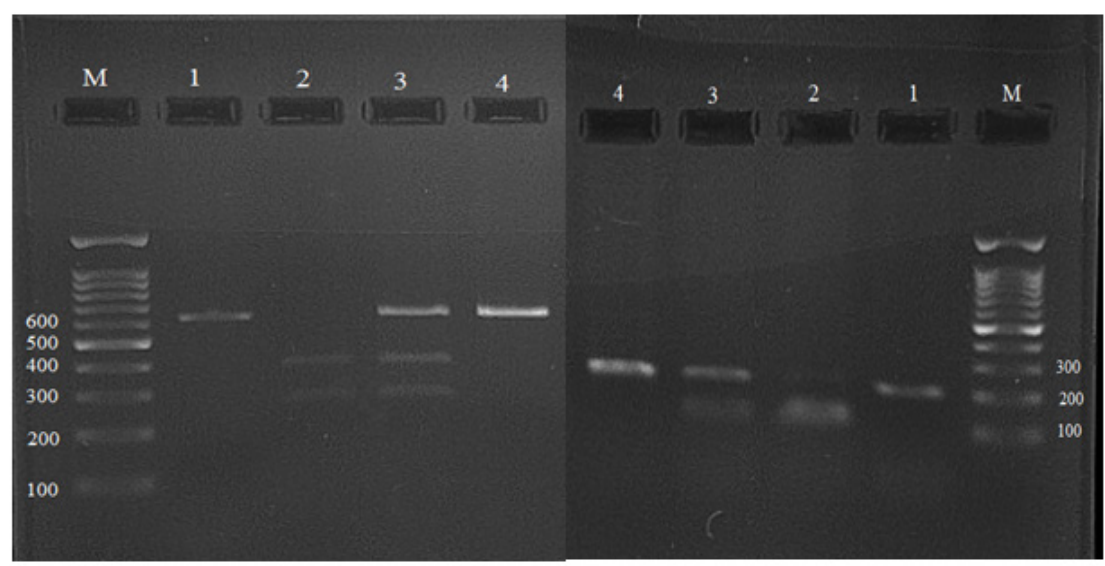

Figure 1. Representative Electrophoresis Gels Obtained by PCR-RFLP for the XRCC1 (rs25487) and OGG1 (rs 1052133) polymorphisms. M is DNA marker ladder contains a 100 base pair (bp) marker and lane 1 is undigested PCR-amplified product. The left panel is for the XRCC1 (rs25487) polymorphism: lane 2 is genotype AA for Gln / Gln: 375 bp, 240 bp; lane 3 is genotype AG for Arg/Gln: 615 bp, 375 bp, 240 bp and lane 4 is genotype GG for Arg/Arg: 615 bp. The right panel is for the OGG1 (rs 1052133) polymorphism: lane 2 is genotype GG for Cys/Cys: 100 bp; lane 3 is genotype CG for Ser/Cys: 100 bp, 200 bp; and lane 4 is genotype CC for Ser/Ser: 200 bp. 
Table 1. Details of PCR and RFLP Procedures and Observed Products

\begin{tabular}{|c|c|c|c|c|c|}
\hline Genotype & Primers (forward and reverse) & PCR conditions & $\begin{array}{l}\text { PCR } \\
\text { product }\end{array}$ & $\begin{array}{l}\text { Restriction } \\
\text { enzyme }\end{array}$ & Restriction products \\
\hline $\begin{array}{l}\text { OGG1 } \\
(r s 1052133)\end{array}$ & $\begin{array}{l}\text { 5-GGAAGGTGCTTGGGAAT-3 } \\
\text { 5-ACTGTCACTAGTCTCACCAG-3 }\end{array}$ & $\begin{array}{c}25 \mu 1 \text { of PCR mixture: } 8 \text { ul master } \\
\text { mix with } 3 \mu 1 \text { DNA and } 14 \mu 1 \mathrm{dw} \text {. } \\
35 \text { cycles: } 95^{\circ} \mathrm{C} 1 \mathrm{~min}, 60^{\circ} \mathrm{C} \\
1 \mathrm{~min}, 75^{\circ} \mathrm{C} 1 \mathrm{~min}\end{array}$ & $200 \mathrm{bp}$ & Fnu4HI & $\begin{array}{c}\text { Ser/Ser: } 200 \text { bp } \\
\text { Ser/Cys: } 100 \text { bp, } 200 \text { bp } \\
\text { Cys/Cys: } 100 \text { bp +100 bp }\end{array}$ \\
\hline $\begin{array}{l}\text { XRCC1 } \\
(r s 25487)\end{array}$ & $\begin{array}{l}\text { 5-TTGTGCTTTCTCTGTGTCCA-3 } \\
\text { 5-TCCTCCAGCCTTTTCTGATA-3 }\end{array}$ & $\begin{array}{l}25 \mu 1 \text { of PCR mixture: } 8 \mu 1 \text { master } \\
\text { mix with } 3 \text { ul DNA and } 14 \mu 1 \mathrm{dw} \text {. } \\
35 \text { cycles: } 95^{\circ} \mathrm{C} 1 \mathrm{~min}, 60^{\circ} \mathrm{C} \\
1 \mathrm{~min}, 75^{\circ} \mathrm{C} 1 \mathrm{~min}\end{array}$ & $615 \mathrm{bp}$ & Msp1 & $\begin{array}{c}\text { Gln / Gln: } 375 \text { bp, } 240 \mathrm{bp} \\
\text { Arg/Gln: } 615 \mathrm{bp}, 375 \mathrm{bp}, \\
240 \mathrm{bp} \\
\text { Arg/Arg: } 615 \mathrm{bp}\end{array}$ \\
\hline
\end{tabular}

${ }^{1}$ Distilled water

and 104 controls $(69.3 \%)$ more than 50 years $(p=0.7)$. 82 patients were male and 68 were female $(54.7 \%$ and $45.3 \%$ respectively), while 70 healthy controls were male $(46.7 \%)$ and 80 were female $(53.3 \%)$. 40 out of 150 patients were smoker $(26.7 \%)$ and 44 out of 150 controls $(29.3 \%)$ were smoker. There were no significant differences in parameters of mean age $(p=0.8)$, gender $(p=0.16)$ and smoking $(p=0.7)$ between the patients and controls. In 85 patients cancers located in colon (56.7\%) and 65 patients suffered from rectal cancer (43.3\%); 74 cancers were in stage I and II (49.3\%) and 76 in stages III and IV (50.7\%). Among 18 patients metastasis were detected $(12 \%)$, while in 132 ones, metastasis did not reported (88\%). Representative PCR-based restriction analyses for the XRCC1 (rs25487) and OGG1 (rs1052133) polymorphisms are shown in Figure 1.

The distributions of the genotype and allele frequencies for XRCC1 (rs25487) and OGG1 (rs1052133) polymorphisms in patient and control groups are represented in Table 2. We found that the frequency of the Gln (A) allele of XRCC1 (rs25487) was significantly higher in CRC patients than in controls (55.0\% vs. $65.3 \%$, $\mathrm{p}=0.01$, OR: $1.54,95 \%$ CI 1.1-2.1). Also, frequency of the Gln/Gln genotype of XRCC1 (rs25487) was higher in $\mathrm{CRC}$ patients than in controls. No significant association was found between the Cys allele and the Ser/Cys genotype of OGG1 (rs 1052133) in CRC patients as compared with controls. Furthermore, the associations of genetic models with CRC risk in each polymorphism were evaluated. For XRCC1 (rs25487) polymorphism, significantly increased cancer risk was seen in the recessive genetic model. Influence of interaction between demographic and clinical characteristics of $C R C$ and XRCC1 (rs25487) (Table 3) and $O G G 1$ ( $r s 1052133$ ) (data not shown) polymorphisms have been displayed. Our results demonstrate a positive correlation between XRCC1 (rs25487) genotypes and some demographic characteristics in patient and control groups, such as smoking and age more than 50 years. Simultaneously, no differences in frequencies of the OGG1 (rs 1052133) genotypes were found in patient and control groups in all demographic features. In addition, association between XRCC1 gene polymorphism and pathologic characteristics is shown in Table 4, though for OGG1 (rs1052133) polymorphism the data is not shown.

\section{Discussion}

The DNA repair system has an important role in conserving genetic stability. Polymorphisms in DNA repair genes can decrease the repair capacity of DNA, which may lead to development of different cancers including CRC (Goode et al., 2002). DNA damage can be caused by endogenous oxidation, deamination, or alkylation, these are repaired mainly by the base excision mechanism.

Table 2. Comparison of Genotypes and Alleles Frequencies of each Polymorphism between Patients and Controls Groups

\begin{tabular}{|c|c|c|c|c|c|c|}
\hline \multirow[t]{2}{*}{ Genotype/Allele } & \multirow{2}{*}{$\begin{array}{c}\text { Patients } \\
\mathrm{N}=150(\%)\end{array}$} & \multirow{2}{*}{$\begin{array}{c}\text { Controls } \\
\mathrm{N}=150(\%)\end{array}$} & \multirow[t]{2}{*}{ OR $(95 \% \mathrm{CI})^{2}$} & \multirow[t]{2}{*}{$P$-value } & \multicolumn{2}{|c|}{ Adjusted $^{3}$} \\
\hline & & & & & OR $(95 \% \mathrm{CI})$ & $P$-value \\
\hline \multicolumn{7}{|c|}{ XRCC1 Arg399Gln (rs25487) } \\
\hline $\operatorname{Arg} / \operatorname{Arg}(G G)$ & $39(26.0 \%)$ & $52(34.7 \%)$ & 1 (reference) & & & \\
\hline $\mathrm{Arg} / \mathrm{Gln}(\mathrm{GA})$ & $87(58.0 \%)$ & $92(61.3 \%)$ & $1.2(0.7-2.09)$ & 0.3 & $1.33(0.76-2.35)$ & 0.3 \\
\hline Gln / Gln (AA) & $24(16.0 \%)$ & $6(4.0 \%)$ & $5.3(1.9-14.2)$ & 0.001 & $7.20(2.3-22.1)$ & 0.001 \\
\hline $\operatorname{Arg}(\mathrm{G})$ & $135(45.0 \%)$ & $104(34.7 \%)$ & 1 (reference) & & & \\
\hline $\mathrm{Gln}(\mathrm{A})$ & $165(55.0 \%)$ & $196(65.3 \%)$ & $1.54(1.1-2.1)$ & 0.01 & & \\
\hline $\mathrm{AA}$ vs $\mathrm{GG}+\mathrm{GA}$ & $127(84.7 \%)$ & $144(96.0 \%)$ & $4.34(1.71-11.02)$ & 0.001 & $5.3(1.9-13.3)$ & 0.001 \\
\hline \multicolumn{7}{|c|}{ OGG1 Ser326Cys (rs1052133) } \\
\hline Ser/Ser (CC) & $91(48.9 \%)$ & $95(51.1 \%)$ & 1 (reference) & & & \\
\hline Ser/Cys (CG) & $57(51.4 \%)$ & $54(48.6 \%)$ & $1.1(0.6-1.7)$ & 0.6 & $1.03(0.7-1.7)$ & 0.2 \\
\hline Cys/Cys (GG) & $2(2.2 \%)$ & $1(1.0 \%)$ & $2.08(0.2-23)$ & 0.5 & $3.08(0.3-36)$ & 0.3 \\
\hline $\operatorname{Ser}(C)$ & $239(79.7 \%)$ & $244(81.3 \%)$ & 1 (reference) & & & \\
\hline Cys (G) & $61(20.3 \%)$ & $56(18.7 \%)$ & $1.09(0.7-1.6)$ & 0.6 & & \\
\hline
\end{tabular}

${ }^{2}$ Crude OR; ${ }^{3}$ Adjusted for gender, age, smoking; Significant values are shown in bold. 
Table 3. Influence of Interaction between Clinical and Demographics Characteristics of CRC and XRCC1 (rs25487) Gene Polymorphism

\begin{tabular}{|c|c|c|c|c|c|c|}
\hline Parameters & Patients (number) & controls (number) & OR $(\mathrm{CI} 95 \%)^{4}$ & $P$-value & $\mathrm{OR}(\mathrm{CI} 95 \%)^{5}$ & $P$-value \\
\hline \multicolumn{7}{|l|}{ Gender } \\
\hline Man & 82 & 70 & & & & \\
\hline Arg/Arg & 28 & 26 & 1 (reference) & & 1 (reference) & \\
\hline $\mathrm{Arg} / \mathrm{Gln}$ & 38 & 41 & $1.2(0.5-2.3)$ & 0.6 & $0.9(0.4-2)$ & 0.9 \\
\hline $\mathrm{G} \ln / \mathrm{G} \ln$ & 16 & 3 & $4.9(1.3-18)$ & 0.02 & $8.6(1.7-41)$ & 0.007 \\
\hline AA vs $\mathrm{GG}+\mathrm{GA}$ & 66 & 67 & $2.3(1.2-4.4)$ & 0.01 & $8.1(2-32)$ & 0.003 \\
\hline Woman & 68 & 80 & & & & \\
\hline Arg/Arg & 11 & 26 & 1 (reference) & & 1 (reference) & \\
\hline Arg/Gln & 49 & 51 & $0.4(0.1-0.9)$ & 0.04 & $2.1(0.9-4.7)$ & 0.07 \\
\hline Gln / Gln & 8 & 3 & $6.3(1.4-28.3)$ & 0.01 & $6.8(1.2-36)$ & 0.02 \\
\hline $\mathrm{AA}$ vs $\mathrm{GG}+\mathrm{GA}$ & 60 & 7 & $1.8(0.9-3.5)$ & 0.07 & $3.8(0.8-17)$ & 0.07 \\
\hline \multicolumn{7}{|l|}{ Smoking } \\
\hline Yes & 40 & 44 & & & & \\
\hline Arg/Arg & 9 & 17 & 1 (reference) & & 1 (reference) & \\
\hline $\mathrm{Arg} / \mathrm{Gln}$ & 16 & 25 & $1.2(0.4-3.3)$ & 0.7 & $1.1(.03-4)$ & 0.7 \\
\hline $\mathrm{Gln} / \mathrm{G} \ln$ & 15 & 2 & $14.1(2.6-76)$ & 0.002 & $21(3-140)$ & 0.002 \\
\hline AA vs $\mathrm{GG}+\mathrm{GA}$ & 25 & 42 & $12.6(2.6-59)$ & 0.001 & $13(3-65)$ & 0.002 \\
\hline No & 110 & 106 & 1 (reference) & & 1 (reference) & \\
\hline Arg/Arg & 30 & 35 & $1.2(0.6-2.2)$ & 0.4 & $1.5(0.8-2.9)$ & 0.1 \\
\hline Arg/Gln & 71 & 67 & $2.6(0.7-9.3)$ & 0.1 & $3.5(0.8-14.8)$ & 0.08 \\
\hline Gln / Gln & 9 & 4 & $2.2(0.6-7.6)$ & 0.1 & $2.1(0.6-7.2)$ & 0.2 \\
\hline $\mathrm{AA}$ vs $\mathrm{GG}+\mathrm{GA}$ & 80 & 71 & $2.2(0.6-7.6)$ & 0.1 & $2.1(0.6-7.4)$ & 0.2 \\
\hline \multicolumn{7}{|l|}{ age } \\
\hline$<50$ & 49 & 46 & & & & \\
\hline Arg/Arg & 15 & 17 & 1 (reference) & & 1 (reference) & \\
\hline Arg/Gln & 27 & 29 & $1.05(0.4-2.5)$ & 0.9 & $1.1(0.3-2.6)$ & 0.9 \\
\hline Gln / Gln & 7 & 0 & ----------- & & ----------- & \\
\hline $\mathrm{AA}$ vs $\mathrm{GG}+\mathrm{GA}$ & 42 & 46 & ----------- & & ----------- & \\
\hline$>50$ & 101 & 104 & & & & \\
\hline Arg/Arg & 24 & 35 & 1 (reference) & & 1 (reference) & \\
\hline $\mathrm{Arg} / \mathrm{Gln}$ & 60 & 63 & $1.3(0.7-2.6)$ & 0.3 & $1.5(0.7-3)$ & 0.2 \\
\hline Gln / Gln & 17 & 6 & $4.1(1.4-11.1)$ & 0.009 & $6.3(1.8-20.6)$ & 0.003 \\
\hline $\mathrm{AA}$ vs $\mathrm{GG}+\mathrm{GA}$ & 84 & 98 & $3.3(1.2-8.7)$ & 0.01 & $3.4(1.2-9.6)$ & 0.01 \\
\hline
\end{tabular}

${ }^{4}$ Crude OR; ${ }^{5}$ Adjusted for gender, age, smoking; Significant values are shown in bold.

The XRCC1 and OGG1 genes encode proteins that play critical roles in the base excision repair pathway (Karahalil et al., 2012). In this study, we aim to test the hypothesis that whether polymorphism in these genes influences the risk of CRC. The outcomes of some investigation about the association of XRCC1 (rs25487) polymorphism with colorectal cancer risk have been contradictory. For example, two recent studies indicated association with increased risk of colorectal cancer (Karam et al., 2016; Abu Halim et al., 2016), while a case-control study in Sweden found no association with CRC risk (Salimzadeh et al., 2020). Also, other findings about the association of OGG1 (rs1052133) polymorphism with susceptibility to CRC remain controversial (Lai et al., 2016; Zou et al., 2016). The results of our study demonstrate that the frequency of the Gln allele is significantly higher in CRC patients than in controls and is associated with the risk of colorectal cancer. Individuals with 399Gln homozygote genotype have more than 5 folds greater risk of colorectal cancer than those with the homozygous 399Arg genotype. Significant interactions were found between this polymorphism and smoking in smoker patients as compared to smoker controls and also with age more than 50 years. Our findings are consistent with the results of Fouad et al. in Egypt: they observed increased risk of colorectal cancer associated with the 399Gln allele (Fouad et al., 2017). In contrast, a study in the Italian population reported no differences among the XRCC1 (rs25487) allele and the risk of colorectal cancer (Improta et al., 2008).

The biological interaction between XRCC1 polymorphism and smoking in colorectal cancer risk 
Table 4. Association between XRCC1 Gene Polymorphism and Tomur Characteristics

\begin{tabular}{|c|c|c|c|}
\hline \multirow[t]{2}{*}{ Variables } & \multicolumn{2}{|c|}{ Cases $(n=150)$} & \multirow[b]{2}{*}{ OR $(95 \% \mathrm{CI}) ; \mathrm{p}$} \\
\hline & Group I & Group II & \\
\hline Tumor location & Colon $=49(42.9 \%)$ & Rectum $=65(57.1 \%)$ & \\
\hline $\operatorname{Arg} / \operatorname{Arg} ; \mathrm{n}=39$ & $21(53.8 \%)$ & $18(46.2 \%)$ & 1 (Ref) \\
\hline $\mathrm{Arg} / \mathrm{Gln} ; \mathrm{n}=87$ & $49(56.3 \%)$ & $38(43.7 \%)$ & $0.9(0.4-1.9) ; 0.5$ \\
\hline $\mathrm{Gln} / \mathrm{Gln} ; \mathrm{n}=24$ & $15(62.5 \%)$ & $9(37.5 \%)$ & $0.7(0.2-1.9) ; 0.7$ \\
\hline AA vs $\mathrm{GG}+\mathrm{GA} ; \mathrm{n}=126$ & $70(55.6 \%)$ & $56(44.4 \%)$ & $0.7(0.3-1.8) ; 0.5$ \\
\hline Metastasis & Yes $=18(12 \%)$ & No $=132(88 \%)$ & \\
\hline Arg/Arg; $\mathrm{n}=39$ & $4(10.3 \%)$ & $35(89.7 \%)$ & 1 (Ref) \\
\hline $\operatorname{Arg} / \mathrm{Gln} ; \mathrm{n}=87$ & $8(9.2 \%)$ & $79(90.8 \%)$ & $1.1(0.3-3.9) ; 0.8$ \\
\hline Gln / Gln; $\mathrm{n}=24$ & $6(25 \%)$ & $18(75 \%)$ & $0.3(0.08-1.3) ; 0.1$ \\
\hline AA vs $\mathrm{GG}+\mathrm{GA} ; \mathrm{n}=126$ & $12(9.5 \%)$ & $114(90.5 \%)$ & $0.3(0.1-0.9) ; 0.04$ \\
\hline Stage & $\mathrm{I}+\mathrm{II}=74(49.3 \%)$ & $\mathrm{III}+\mathrm{IV}=76(50.7 \%)$ & \\
\hline Arg/Arg; $\mathrm{n}=39$ & $25(64.1 \%)$ & $14(35.9 \%)$ & 1 (Ref) \\
\hline $\operatorname{Arg} / \mathrm{Gln} ; \mathrm{n}=87$ & $39(44.8 \%)$ & $48(55.2 \%)$ & $2.1(1-4.7) ; 0.04$ \\
\hline Gln / Gln; n = 24 & $10(41.7 \%)$ & $14(58.3 \%)$ & $2.5(0.8-7.09) ; 0.08$ \\
\hline $\mathrm{AA}$ vs $\mathrm{GG}+\mathrm{GA} ; \mathrm{n}=126$ & $64(50.8 \%)$ & $62(49.2 \%)$ & $1.4(0.5-3.4) ; 0.4$ \\
\hline
\end{tabular}

Significant values are shown in bold

is probable. Cigarette smoking is a plentiful source of genotoxins such as reactive oxygen species and chemical carcinogens that can cause single and double-stranded breaks and base adduct formation (Stern et al., 2007). Smoking has been shown to be associated with increased risk of colorectal cancer consistent with our study (Weiss et al., 2005; Tsong et al., 2007).

Our data analysis revealed no significant difference between CRC patients and controls in the genotypic and allelic frequencies of the $O G G 1$ ( $r$ s1052133) polymorphism. Zou et al., (2016) in a meta-analysis found no major difference in that genotype distribution between patients and controls, this confirms our results. In contrast to our findings, OGG1 (rs1052133) polymorphism had significant association with increased risk of CRC in the Polish population according to Kabzinski et al., (2018). Based on our results, XRCC1 polymorphism may be considered a substantial biomarker for cancer screening in high risk persons and for supporting these patients by prophylactic interventions and specific therapeutic methods. Due to our limited sample size, further studies with large sample size across diverse ethnic populations should be performed to elucidate the association between XRCC1 (rs25487) and OGG1 (rs 1052133) polymorphisms and $\mathrm{CRC}$ in the Iranian population.

\section{Acknowledgements}

The authors are grateful to the Ahvaz Jundishapur University of Medical Sciences for their financial support. They thank nurses of Imam Khomeini and Golestan educational hospitals of Ahvaz: Mrs. Sara Shahidi and Mahnaz Farazpi, for helping in data collection. Our thanks also to the professors and technicians of the department of medical genetics, medical faculty of University, who helped us in this study.

\section{Funding Statement}

This research is a part of Msc thesis of Mr. Seyed Mohammad Hosseini, student in Human Genetics, with number: CMRC-9620. The investigation was supported by Deputy of Research, Ahvaz Jundishapur University of Medical Sciences, Iran.

\section{Statement conflict of Interest}

The authors declare that they have no conflict of interest.

\section{References}

Abu Halim NH, Chong ETJ, Goh LPW, et al (2016). Variant alleles in XRCC1 Arg194Trp and Arg399Gln polymorphisms increase risk of gastrointestinal cancer in Sabah, North Borneo. Asian Pac J Cancer Prev, 7, 1925-31.

Arnold M, Sierra MS, Laversanne M, et al (2017). Global patterns and trends in colorectal cancer incidence and mortality. Gut, 66, 683-91.

Boiteux S, Radicella JP (2000). The human OGG1 gene: structure, functions, and its implication in the process of carcinogenesis. Arch Biochem Biophys, 377, 1-8.

de Jong MM, Nolte IM, te Meerman GJ, et al (2002). Low-penetrance genes and their involvement in colorectal cancer susceptibility. Cancer Epidemiol Biomarkers Prev, 11, 1332-52.

Fan J, Otterlei M, Wong HK, Tomkinson AE, Wilson III DM (2004). XRCC1 co-localizes and physically interacts with PCNA. Nucleic Acids Res, 32, 2193-201.

Fouad H, Sabry D, Morsi H, Shehab H, Abuzaid NF (2017). XRCC1 gene polymorphisms and miR-21 expression in patients with colorectal carcinoma. Eurasian J Med, 49, $132-6$.

Goode EL, Ulrich CM, Potter JD (2002). Polymorphisms in DNA repair genes and associations with cancer risk. Cancer Epidemiol Biomarkers Prev, 11, 1513-30.

Hung RJ, Hall J, Brennan P, Boffetta P (2005). Genetic polymorphisms in the base excision repair pathway and 
cancer risk: a HuGE review. Am J Epidemiol, 162, 925-42.

Huang Y, Li X, He J, et al (2015). Genetic polymorphisms in XRCC1 genes and colorectal cancer susceptibility. World $J$ Surg Oncol, 13, 1-7.

Improta G, Sgambato A, Bianchino G, et al (2008). Polymorphisms of the DNA repair genes XRCC1 and XRCC3 and risk of lung and colorectal cancer: a case-control study in a Southern Italian population. Anticancer Res, 28, 2941-6.

Kabzinski J, Walczak A, Dziki A, et al (2018). Impact of the Ser326Cys polymorphism of the OGG1 gene on the level of oxidative DNA damage in patients with colorectal cancer. Pol Przegl Chir, 90, 13-5.

Karahalil B, Bohr V, Wilson III DM (2012). Impact of DNA polymorphisms in key DNA base excision repair proteins on cancer risk. Hum Exp Toxicol, 31, 981-1005.

Karam RA, Al Jiffry BO, Al Saeed M, et al (2016). DNA repair genes polymorphisms and risk of colorectal cancer in Saudi patients. Arab J Gastroenterol, 17, 117-20.

Kohno T, Shinmura K, Tosaka M, et al (1998). Genetic polymorphisms and alternative splicing of the hOGG1 gene, that is involved in the repair of 8-hydroxyguanine in damaged DNA. Oncogene, 16, 3219-15.

Lai CY, Hsieh LL, Tang R, et al (2016). Association between polymorphisms of APE1 and OGG1 and risk of colorectal cancer in Taiwan. World J Gastroenterol, 22, 3372-80.

Mohrenweiser H, Carrano A, Fertitta A, et al (1989). Refined mapping of the three DNA repair genes, ERCC1, ERCC2, and XRCC1, on human chromosome 19. Cytogenet Genome Res, 52, 11-4.

Monaco R, Rosal R, Dolan MA, Pincus MR, Brandt-Rauf PW (2007). Conformational effects of a common codon 399 polymorphism on the BRCT1 domain of the XRCC1 protein. Protein J, 26, 541-6.

Nazarkina ZK, Khodyreva SN, Marsin S, Lavrik OI, Radicella JP (2007). XRCC1 interactions with base excision repair DNA intermediates. DNA Repair, 6, 254-64.

Nissar S, Sameer AS, Rasool R, Rashid F (2014). DNA Repair Gene-XRCC1 in relation to genome instability and role in colorectal carcinogenesis. Oncol Res Treat, 37, 418-22.

Pardini B, Naccarati A, Novotny J, et al (2008). DNA repair genetic polymorphisms and risk of colorectal cancer in the Czech Republic. Mutat Res, 638, 146-53.

Safaee A, Fatemi SR, Ashtari S, et al (2012). Four years incidence rate of colorectal cancer in Iran: a survey of national cancer registry data-implications for screening, Asian Pac J Cancer Prev, 13, 2695-8.

Salimzadeh H, Lindskog EB, Gustavsson B, Wettergren Y, Ljungman D (2020). Association of DNA repair gene variants with colorectal cancer: risk, toxicity, and survival. BMC Cancer, 20, 409-19.

Simonelli V, Mazzei F, D’Errico M, Dogliotti E (2012). Gene susceptibility to oxidative damage: from single nucleotide polymorphisms to function. Mutat Res, 731, 1-13.

Stern MC, Conti DV, Siegmund KD, et al (2007). DNA repair single-nucleotide polymorphisms in colorectal cancer and their role as modifiers of the effect of cigarette smoking and alcohol in the Singapore Chinese Health Study. Cancer Epidemiol Biomarkers Prev, 16, 2363-72.

Tsong W, Koh W, Yuan J, Wang R, Sun C (2007). Cigarettes and alcohol in relation to colorectal cancer: the Singapore Chinese Health Study. Br J Cancer, 96, 821-7.

Weiss J, Goode EL, Ladiges W, Ulrich CM (2005). Polymorphic variation in hOGG1 and risk of cancer: a review of the functional and epidemiologic literature. Mol Carcinog, 42, 127-41.

Wang Y, Gao X, Wei F, et al (2015). The hOGG1 Ser326Cys polymorphism contributes to digestive system cancer susceptibility: evidence from 48 case-control studies. Tumor Biol, 36, 1029-38.

Wood RD, Mitchell M, Sgouros J, Lindahl T (2001). Human DNA repair genes. Science, 291, 1284-9.

Zou H, Li Q, Xia W, et al (2016). Association between the OGG1 Ser326Cys polymorphism and cancer risk: Evidence from 152 Case-Control Studies. J Cancer, 7, 1273-80.

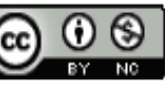

This work is licensed under a Creative Commons AttributionNon Commercial 4.0 International License. 